\title{
ANALISIS FRAMING PEMBERITAAN MEDIA ONLINE MENGENAI MUNDURNYA RATU TISHA DARI JABATAN SEKRETARIS JENDERAL PSSI
}

\section{Fadli Muhammad Athalarik, Fina Zahra}

Fakultas Ilmu Komunikasi, Universitas Bhayangkara Jakarta Raya, Indonesia

Email: fadli.athalarik@dsn.ubharajaya.ac.id, fina.zahra@dsn.ubharajaya.ac.id

\begin{abstract}
Abstrak
Mundurnya Ratu Tisha dari jabatannya sebagai Sekretaris Jenderal PSSI disayangkan oleh banyak pihak. Hal itu dikarenakan sudah banyak pencapaian yang didapatkan oleh Ratu Tisha baik untuk PSSI secara organisasi, maupun Timnas Indonesia sebagai ujung dari prestasi sepakbola itu sendiri. Respons berbagai insan sepakbola ini yang diliput oleh banyak media untuk menjadi pemberitaan. Penelitian ini bertujuan untuk untuk mengetahui bagaimanakah media online Kompas dan Detik membingkai berita tentang mundurnya Ratu Tisha dari jabatan Sekretariat Jenderal PSSI berdasarkan perangkat framing Zhongdang Pan dan Gerald M. Kosicki. Penelitian ini menggunakan metode penelitian Kualitatif deskriptif dan menggunakan analisis framing model analisis Pan dan Kosicki dengan menggunakan empat dimensi struktural teks berita yaitu sintaksis, skrip, tematik, dan retoris. sebagai Teknik analisis datanya. Penelitian ini menemukan fakta kalau Detik.com cenderung lebih tendensius dalam memberikan headline berita ketimbang Kompas.com. Selain itu, penelitian ini juga menemukan fakta bahwa Kompas.com cenderung lebih deskriptif dan hanya sedikit memberikan pernyataan dalam penulisan beritanya.
\end{abstract}

Kata kunci: Framing; pemberitaan media online; PSSI

\section{Abstract}

The resignation of Ratu Tisha from his position as Secretary General of PSSI consisted of many parties. That's because there is a lot that Ratu Tisha can enjoy, both for PSSI as an organization, as well as for the Indonesian national team as the end of the football achievement itself. The responses of various football people were covered by many media to become news. This study aims to find out how the online media Kompas and Detik frame the news about the resignation of Ratu Tisha from the PSSI General Secretariat position based on the framing device of Zhongdang Pan and Gerald M. Kosicki. This study uses descriptive qualitative research methods and uses analysis of Pan and Kosicki's framing model analysis using four structural dimensions of news texts, namely syntax, script, thematic, and rhetorical. as a data analysis technique. This study finds the fact that Detik.com tends to be more serious in providing headlines than Kompas.com. In addition, this study also found the fact that Kompas.com tends to be more descriptive and only gives a few statements in its news writing.

$\begin{array}{ll}\text { How to cite: } & \text { Athalarik, F, M., Zahra, F., (2021) Analisis Framing Pemberitaan Media Online Mengenai } \\ & \text { Mundurnya Ratu Tisha Dari Jabatan Sekretaris Jenderal PSSI, Syntax Idea, 3(12), } \\ & \text { https://doi.org/10.36418/syntax-idea.v3i12.1665 } \\ & \text { 2684-883X } \\ \text { E-ISSN: } & \text { Ridwan Institute } \\ \text { Published by: } & \end{array}$


Keywords: Framing; online media coverage; PSSI

Received: 2021-11-22; Accepted: 2021-12-05; Published: 2021-12-20

\section{Pendahuluan}

Sepak bola merupakan olah raga rakyat yang sangat sering dimainkan oleh banyak orang. Tak peduli siapapun yang bermain, tak menjadi masalah dimanapun lokasinya, hampir semua orang khususnya pria sangat menyukai olah raga tersebut. Sepak bola juga dianggap pemersatu rakyat, bayangkan saja orang-orang rela berbondong-bondong secara sukarela untuk menonton pertandingan sepak bola. Berbagai yel-yel dinyanyikan sebagai dukungan terhadap tim kesayangan. Tak jarang juga kafe, warung kopi, hingga pos satpam ramai kedatangan warga yang ingin menonton Bersama (Hodijah, 2015).

Tak bisa dipungkiri, sepak bola di Indonesia menjadi komoditi panas di jagat pertelevisian nasional. Bahkan menurut CNN Indonesia, Helmy Yahya saat masih menjabat sebagai Direktur Utama TVRI menyatakan bahwa hak siar Liga Indonesia lebih mahal antara empat atau lima kali lipat dibandingkan Liga Inggris (CNN Indonesia, 2021). Hal tersebut membuktikan bahwa antusias dan permintaan supporter terhadap sepak bola Nasional sangatlah besar.

Namun sangat disayangkan, antusias yang tinggi dari supporter tidak berjalan berdampingan dengan baiknya sistem organisasi yang ada di dalam tubuh Organisasi tertinggi dalam sepak bola nasional, PSSI (Novianti, 2019).

Tahun 2020 memanglah kelabu bagi sebagian besar umat manusia di muka bumi ini, tak terkecuali PSSI. Setelah harus menelan pil pahit tidak mampu meneruskan kompetisi Shopee Liga 1 musim 2020, PSSI harus menerima kenyataan bahwa Sekretaris Jenderalnya, Ratu Tisha resmi mengundurkan diri pada April 2020.

Tak bisa dipungkiri, walaupun belum cukup mampu mengangkat prestasi Tim Nasional Indonesia. Namun kehadirannya sejak Juli 2017 itu mampu secara perlahan merapihkan sistem organisasi yang ada di dalam tubuh PSSI. Jika menengok apa yang telah dilakukan oleh Ratu Tisha, banyak sekali legacy hingga prestasi yang ia persembahkan di persepakbolaan Indonesia.

Pertama, Ratu Tisha menjadi wanita pertama yang duduk sebagai sekjen PSSI. Saat itu dia menggantikan peran dari Ade Wellington yang memutuskan mengundurkan diri April 2017. Kedua, Membawa Indonesia menjadi tuan rumah Piala Dunia U-20 2021. Tisha menjadi sosok penting saat melakukan bidding ke FIFA. Sejumlah persyaratan sukses membuat FIFA memilih Indonesia, Ketiga, Di era Ratu Tisha, kompetisi Liga 1 Putri resmi digelar. Keempat, Ratu Tisha menjadi wakil Presiden wanita pertama AFF di Asia Tenggara. Kelima, Ratu Tisha menggalakkan kompetisi dari level amatir hingga pro elite. Prestasi di bidang futsal pun turut terdongkarak di level Asia (Maulana, 2020).

Menengok dari apa yang telah dicapai, rasanya menjadi suatu hal yang sangat disayangkan jika Ratu Tisha harus menanggalkan jabatannya sebagai Sekretaris Jenderal. Mengingat Ratu Tisha adalah orang yang cukup berpengaruh, ini juga yang 
menjadi urgensi penelitian mengapa peneliti mengambil masalah ini sebagai objek penelitian ini.

Maka tak heran dia menjadi topik perbincangan di belantika sepakbola Indonesia, khususnya Media. Terlebih pada era saat ini teknologi komunikasi semakin berkembang Salah satu perkembangan yang sangat signifikan ialah kehadiran new media seperti situs media online. Hal tersebut terjadi dikarenakan kebutuhan masyarakat terhadap informasi. Situs berita online mempunyai ciri-ciri yang sama seperti media massa lain yaitu menyediakan informasi dan berita-berita yang aktual. Informasi yang disampaikan dalam media massa sangat bervariasi seperti, permasalahan sosial, budaya, ekonomi, politik, gender, dan masih banyak lainnya yang berkaitan dengan aspek kehidupan manusia.

Media Online memiliki fungsi yang sangat vital dalam menjalankan perannya sebagai pemberi kabar atau informasi bagi masyarakat. Salah satu keunggulannya yaitu kecepatan dan ketepatan dalam memberitakan menjadi pembeda antara media online dengan media konvensional. Bahkan media online memiliki keunggulan tidak ada pembatas antar negara atau batas wilayah, sehingga bisa di jangkau orang-orang untuk membaca berita (Mustika, 2018).

Dalam penelitian ini, peneliti memilih Kompas.com dan Detik.com sebagai media yang akan menjadi media yang diteliti secara analisis framing. Kompas.com merupakan salah satu inisiator media daring di Indonesia, kompas.com hadir di Internet pada 14 September 1995 dengan nama Kompas Online. Sementara itu, Detikcom ialah sebuah portal laman yang berisi berita dan artikel online di Indonesia yang lahir pada tahun 1998. Namun, Sejak tanggal 3 Agustus 2011, PT Trans Corporation mengakuisisi Detikcom menjadi bagian dari perusahaan tersebut, salah satu anak perusahaan CT Corp (Pratiwi, 2018).

Penelitian mengenai framing terhadap pemberitaan sepakbola Nasional sebelumnya sudah pernah dibuat oleh Fikry Zahria Emeraldien, Aldi Purnomo, Nasario Wahyu Handoko mengenai Analisis Framing Terhadap Pemberitaan Klub Sepak Bola Persebaya. Dalam penelitian ini menggunakan model analisis framing yang digunakan adalah milik Zhongdang Pan dan Gerald M. Kosicky. Hasil yang didapatkan dari penelitian ini adalah bahwa pembingkaian berita oleh Jawa Pos dan Harian Surya memiliki perbedaan dalam pemberitaannya. Jawa Pos tidak memperlihatkan keberpihakan dalam pemberitaannya, sementara Surya sudah berusaha menyuguhkan berita yang berimbang meski kurang selaras dan kurang memenuhi kelengkapan unsur berita (Handoko, Emeraldien, \& Purnomo, 2020).

Maka dari itu, Mengacu pada latar belakang masalah serta permasalahan yang disampaikan, maka tujuan penelitian ini adalah untuk mengetahui bagaimanakah media online Kompas dan Detik membingkai berita tentang mundurnya Ratu Tisha dari jabatan Sekretariat Jenderal PSSI berdasarkan perangkat framing Zhongdang Pan dan Gerald M. Kosicki. 


\section{Metode Penelitian}

Penelitian ini menggunakan pendekatan kualitatif. Pendekatan kualitatif adalah metode penelitian yang menghasilkan data deskriptif berupa kata-kata tertulis atau lisan dari orang-orang atau perilaku yang dapat diamati. Pendekatan kualitatif dalam penelitian ini dianggap sebagai pendekatan yang komprehensif dan digunakan untuk mendapatkan gambaran yang utuh dalam memaknai realitas tanpa. Sifat penelitian ini adalah deskriptif yang diharapkan dapat memberikan pemahaman yang lebih lengkap tentang subjek berdasarkan tujuannya. Penelitian deskriptif juga memberikan deskripsi mengenai konteks, situasi, dan kejadian, fenomena dari apa yang diamati (Mustika, 2018).

Penelitian ini menggunakan Framing sebagai teori dan Analisis datanya. Framing sendiri menurut Zhongdang Pan dan Kosicky dikutip dari Fikry Zahria Emeraldien, Aldi Purnomo, Nasario Wahyu Handoko telah merumuskan dalam ialah metode untuk mengkonstruksi dan memproses berita. Selain itu, Menurut Zhongdang Pan dan Kosicky dikutip dari Fikry Zahria Emeraldien, Aldi Purnomo, Nasario Wahyu Handoko terdapat dua metode dalam memproses sebuah berita yaitu sosiologis dan psikologis.

Dari sudut pandang psikologis, framing didefinisikan sebagai metode kognitif, dikarenakan metode tersebut menggambarkan bagaimana seseorang memproses informasi dalam dirinya. Di sisi lain, secara sosiologis, framing memiliki peran sebagai pembangun suatu realitas menjadi teridentifikasi, dimengerti dan dipahami, karena di dalam realitas tersebut telah hadir label tertentu (Handoko et al., 2020).

Dalam melakukan framing, Zhongdang Pan dan Kosicky membagi metodenya ke dalam empat bagian, Pertama yaitu struktur sintaksis, struktur ini berkaitan dengan cara wartawan membentuk dan membangun peristiwa, pernyataan, pendapat, kutipan, pengamatan atas peristiwa ke dalam bentuk susunan umum berita. Struktur ini bisa diteliti dari bagian berita (Lead yang dipakai, latar, headline, kutipan yang diambil, dan sebagainya).

Kedua yaitu struktur skrip, struktur ini berkaitan dengan cara wartawan menggambarkan peristiwa ke dalam bentuk berita. Struktur ini mendeskripsikan bagaimana cara wartawan merangkai kata dan cerita sehingga peristitwa tersebut dapat dikemas ke dalam bentuk berita.

Ketiga yaitu struktur tematik, struktur ini berkaitan dengan cara wartawan menyampaikan sudut pandangnya atas peristiwa yang terjadi ke dalam proposisi, kalimat atau hubungan antarkalimat yang membentuk teks secara keseluruhan. Struktur ini mendeskripsikan bagaimana pemahaman itu diwujudkan dalam bentuk yang lebih kecil (Ardy, 2011).

Keempat yaitu struktur retoris, struktur ini berkaitan dengan cara wartawan menyampaikan arti tertentu ke dalam berita. Struktur ini akan menjelaskan juga bagaimana wartawan menggunakan pilihan kata, idiom, grafik, dan gambar yang digunakan, yang fungsinya bukan hanya untuk mendukung tulisan, melainkan juga menekankan arti tertentu kepada pembaca. Kecenderungan wartawan atau institusi 
media dalam memahami suatu peristiwa dapat diamati dari keempat struktur tersebut (Putra \& Larasati, 2021).

Dalam penelitian ini, peneliti menggunakan media online dan berita untuk menjadi objek yang ditelitinya, Media online merupakan sarana komunikasi berupa blog atau website yang digunakan sebagai sarana penyebaran berbagai berita yang berhubungan dengan internet. Media akan melihat sedikit banyak maju atau larut ke arah yang lebih canggih. Media Internet Kehadiran portal berita mulai menjamur dalam bentuk website, baik dalam bentuk forum online maupun dalam format seperti koran online. Menggunakan media online sangat mudah dan mencari berita sangat cepat. Semua pesan yang ada dapat disimpan dan tersedia untuk audiens. Itulah kelebihan media online (Andarista, 2017).

Sementara itu, Berita menurut The New Glorier Webster International Dictionary ialah : (Restendy, 2017).

1. Informasi yang baru mengenai sesuatu yang telah terjadi, atau mengenai sesuatu yang belum diketahui oleh masyarakat.

2. Berita adalah informasi yang disampaikan oleh media semisal surat kabar, radio dan televisi.

3. Berita adalah sesuatu atau seseorang yang dianggap oleh media sebagai subjek yang pantas untuk diberitakan.

Jenis-jenis Berita Ada sejumlah jenis berita yang dikenal di dunia jurnalistik, yang paling popular dan menjadi menu utama surat kabar adalah:

1. Berita Langsung

Berita langsung (straight news) adalah laporan mengenai kejadian yang disampaikan secara tertulis dengan cara yang singkat, padat, lugas, dan apa adanya.. Berita langsung dibagi menjadi dua jenis: berita keras atau hangat (hard news) dan berita lembut atau ringan (soft news) (Rahmawati, 2021).

2. Berita Opini

Berita opini (opinion news) ialah berita tentang opini, pernyataan, atau ide seseorang, biasanya pendapat para cendekiawan, sarjana, ahli, atau pejabat, mengenai suatu peristiwa (Binti, 2018).

3. Berita Interpretatif

Berita interpretaif (interpretative news) ialah berita yang disampaikan berdasarkan pendapat atau penilaian wartawan atau nara sumber yang memiliki keahlian terhadap bidang yang berkaitan dengan berita yang muncul, sehingga berita tersebut ialah sebuahgabungan antara fakta dan interpretasi.

4. Berita Mendalam

Berita mendalam (depth news) adalah berita yang dikembangkan dari berita yang sudah ada sebelumnya, Berita tersebut ditambah dengan rincian-rincian yang semakin menambah isi dari beritanya. Berita tersebut juga dilakukan eksplorasi dengan mencari informasi tambahan dari narasumber atau berita terkait.

5. Berita Penjelasan 
Berita penjelasan (explanatory news) ialah berita yang mendeskripsikan sebuah kejadian secara rinci dan komperehensif. Informasinya disampaikan secara lengkap dengan menambah beberapa argumentasi atau pendapat penulisnya. Berita jenis ini biasanya secara kuantitas banyak sehingga harus disampaikan secara bersambung dan berseri (Harahap, 2019).

6. Berita Penyelidikan

Berita penyelidikan (investigative news) dalah berita yang didapat dan ditulis berdasarkan penelitian atau penyelidikan dari referensi yang bervariasi. Umumnya berita investigasi disampaikan dalam format tulisan feature (Agustiyani, 2016).

Nilai Berita Suatu berita yang mempunyai penilaian yang layak untuk dipublikasikan kepada masyarakat, kelayakan tersebut dinilai dari beberapa unsur, yakni: unsur kejelasan (clarity) tentang kejadiannya, ada unsur kejutannya (surprise), Ada unsur kedekatannya (proximity) secara geografis, serta ada dampak (impact) dan konflik personalnya. Selain itu, terdapat juga unsur-unsur lain yang mencakup berita, yaitu (Chandra, 2018):

1. Aktualitas.

2. Faktual.

3. Penting.

4. Menarik.

Maka dari itu, Pada penelitian ini pengambilan data diperoleh dengan mengunduh berita mengenai mundurnya Ratu Tisha dari jabatan Sekretariat Jenderal PSSI dari Media Online Kompas.com dan Detik.com pada rentang waktu 13-18 April 2020. Dengan rincian sebagai berikut:

Tabel 1

Berita Kompas Mengenai Mundurnya Ratu Tisha

\begin{tabular}{|c|c|c|}
\hline No. & Judul Berita & Tanggal \\
\hline 1 & Pernyataan Lengkap Ratu Tisha Saat Mundur dari Sekjen PSSI & 13 April 2020 \\
\hline 2 & Ratu Tisha Mundur dari PSSI? & 13 April 2020 \\
\hline 3 & $\begin{array}{l}\text { Ratu Tisha Mundur, PSSI Sayangkan, Tak Bisa Cegah dan } \\
\text { Ucap Terima Kasih }\end{array}$ & 13 April 2020 \\
\hline 4 & $\begin{array}{l}\text { Resmi Mundur, Ini Pencapaian Ratu Tisha Selama Jadi Sekjen } \\
\text { PSSI }\end{array}$ & 13 April 2020 \\
\hline 5 & Suka Duka Ratu Tisha Selama di PSSI & 14 April 2020 \\
\hline 6 & $\begin{array}{l}\text { Peninggalan Ratu Tisha, Pengamat: Konyol Jika Sekjen PSSI } \\
\text { Tidak Paham Bola. }\end{array}$ & 15 April 2020 \\
\hline 7 & $\begin{array}{l}\text { Mundur dari PSSI, Ratu Tisha Diminta Menjadi Manajer } \\
\text { Sriwijaya FC }\end{array}$ & 14 April 2020 \\
\hline 8 & Ratu Tisha: Hati Saya kalau Dibelah, Isinya Hanya Sepak Bola & 13 April 2020 \\
\hline 9 & $\begin{array}{l}\text { Perjalanan Ratu Tisha, dari Ikut Master FIFA hingga Jadi } \\
\text { Wakil Presiden AFF }\end{array}$ & 13 April 2020 \\
\hline 10 & Ini Syarat Menjadi Sekjen PSSI Pengganti Ratu Tisha & 14 April 2020 \\
\hline
\end{tabular}




\section{Tabel 2}

Berita Kompas Mengenai Mundurnya Ratu Tisha

\begin{tabular}{llll}
\hline No. & Judul Berita & Tanggal \\
\hline 1 & $\begin{array}{l}\text { Ratu Tisha Mundur dari Sekjen PSSI, Ada } \\
\text { Apa? }\end{array}$ & 14 April 2020 \\
\hline 2 & $\begin{array}{l}\text { Mundur dari Sekjen PSSI, Ratu Tisha } \\
\text { Digantikan Adik Ipar Sang Ketum? }\end{array}$ & 14 April 2020 \\
\hline 3 & Ratu Tisha Mundur dari Kursi Sekjen PSSI & 13 April 2020 \\
\hline 4 & $\begin{array}{l}\text { Ratu Tisha Mundur dari PSSI karena Kritik } \\
\text { Djohar atau Hal Lain? }\end{array}$ & 15 April 2020 \\
\hline 5 & $\begin{array}{l}\text { Mundur Jadi Sekjen PSSI, Ratu Tisha Kok } \\
\text { Masih Puasa Bicara? }\end{array}$ \\
\hline 6 & $\begin{array}{l}\text { Ratu Tisha Mundur dari PSSI, Umuh: } 2020 \\
\text { Mungkin Nyaman Tak Jadi Sekjen Lagi }\end{array}$ \\
\hline 7 & $\begin{array}{l}\text { Kiprah Ratu Tisha Selama Menjabat sebagai } \\
\text { Sekjen PSSI }\end{array}$ & 13 April 2020 \\
\hline 8 & $\begin{array}{l}\text { Exco PSSI: Sekjen Baru PSSI Jangan Seperti } \\
\text { Ratu Tisha }\end{array}$ & 18 April 2020 \\
\hline 9 & $\begin{array}{l}\text { Perpisahan Ratu Tisha: Isi Hati Saya Cuma } \\
\text { Ada Sepakbola }\end{array}$ \\
\hline 10 & $\begin{array}{l}\text { Ratu Tisha Mundur Jadi Sekjen, Ini Respons } \\
\text { Ketum PSSI }\end{array}$ & 13 April 2020 \\
\hline
\end{tabular}

Sumber: detik.com

\section{Hasil dan Pembahasan}

Analisis framing ini dilakukan terhadap berita-berita yang dimuat oleh kompas.com dan detik.com mundurnya Ratu Tisha dari jabatan Sekretariat Jenderal PSSI dari tanggal 13 April 2020 hingga 18 April 2020. Adapun penemuan dan pembahasannya sebagai berikut:

a. Penemuan dan Pembahasan Berita dari Kompas.com

1. Pernyataan Lengkap Ratu Tisha Saat Mundur dari Sekjen PSSI Tanggal: 13 April 2020

Sintaksis: Berdasarkan judul dan lead berita disampaikan bahwa Ratu Tisha mengundurkan diri dari jabatannya sebagai Sekjen PSSI. Hal tersebut diketahui berdasarkan unggahan postingan di Instagram yang berdurasi 1 menit 45 detik. Berita ini juga ditambah dengan kutipan pernyataan langsung yang diunggah di postingan Instagram Ratu Tisha sebagai ungkapan perpisahannya.

Skrip: Dari sisi skrip terdapat ketidaklengkapan fakta yang digambarkan yakni alasan mengapa Ratu Tisha mengundurkan diri dari jabatan tersebut (why) dan dimana ia (Kota atau Negara) mengundurkan diri.

Tematik: Pemberitaan ditulis secara singkat karena hanya menyampaikan berita sesuai dengan postingan Instagram Ratu Tisha. 
Retoris: Dalam berita ini ditambahkan gambar postingan serta caption dan voice over yang dilakukan oleh Ratu Tisha sebagai bukti otentik mundurnya Ratu Tisha.

2. Judul: Ratu Tisha Mundur dari PSSI?

Tanggal: 13 April 2020

Sintaksis: Judul dan lead berita diawali dari gencarnya pemberitaan dan menjadi pembicaraan di akun-akun pemerhati sepakbola nasional bahwa Ratu Tisha akan mundur dari jabatannya sebagai Sekjen di PSSI. Dalam berita ini juga dikutip beberapa tweet yang menyayangkan mundurnya Ratu Tisha, dari akun @garagarabola_dan @Ekomaung. Namun di sisi lain, terdapat berita anggota DPR RI yang juga merupakan mantan ketua PSSI, Djohar Arifin, melayangkan protes kepada Ketua PSSI Mochamad Iriawan terkait kinerja Ratu Tisha. Berita ini ditutup oleh respon oleh beberapa warganet atas pernyataan Djohar Arifin, yaknidari akun@myudhistirafdan@alifmustikoo.

Skrip: Dari sisi skrip pada pemberitaan ini sebenarnya sudah cukup lengkap, hanya saja Kembali lagi kekurangan unsur where yang menyatakan tempat seperti kota atau negara.

Tematik: Dari sisi tematik, sebenarnya paragraf, proporsi kalimat, hubungan antar kalimatnya baik. Hanya saja terdapat satu pembahasan yang menurut peneliti ini diluar konteks pembahasan berita, yakni mengenai munculnya protes dari Djohar Arifin. Karena akan memunculkan dua berita yang berbeda dalam satu publikasi berita. Karena fokus pada berita menanyakan kebenaran apakah mundur atau tidaknya Ratu Tisha.

Retoris: Pada pemberitaan ini, penulis berita mengutip beberapa tweet dari akun-akun pemerhati sepakbola nasional. Yang membuat cukup misterius disini ialah kutipan tweet dari akun @garagarabola_yang mengunggah gambar siluet Wanita dengan ucapan perpisahan. Di sisi lain juga terdapat unggahan tweet dari @ Ekomaung yang tweetnya cukup bermanuver, ia mengatakan bahwa "Mungkin inilah langkah terbaik, kau telah mengalami berbagai pelemahan secara vulgar hingga mundur adalah jalan terbaik. Sejarah akan mencatat, sebagai sekjen perempuan pertama dan termuda kau telah begitu memukau dan menginspirasi. Kesan yang akan sulit disamai siapapun,". Dari kalimat "pelemahan secara vulgar" memunculkan banyak spekulasi dari berbagai pihak.

3. Judul: Ratu Tisha Mundur, PSSI Sayangkan, Tak Bisa Cegah dan Ucap Terima Kasih

Tanggal: 13 April 2020

Sintaksis: Judul dan lead berita diawali dari konfirmasi Ratu Tisha yang mengundurkan diri dari jabatannya di PSSI melalui unggahan di instagram. Pada berita ini juga mengutip pernyataan dari Ratu Tisha di unggahannya di Instagram. Pada pemberitaan ini juga menyampaikan respons dari Wakil Ketua Umum PSSI, Cucu Soemantri yang menyayangkan mundurnya Ratu Tisha. Karena Ratu Tisha yang mempunyai andil dalam banyak kegiatan PSSI. Berita ini juga ditutup 
dengan PSSI yang akan segera mencari pengganti Ratu Tisha di jabatan Sekjen PSSI.

Skrip: Dari aspek where sebagai tempat pengunduran diri tersebut dilaksanakan, why sebagai alasan pengunduran diri, dan how sebagai mengapa Ratu Tisha mengundurkan diri tidak ditemukan disini.

Tematik: Dari sisi tematik, paragraf, proporsi kalimat, hubungan antar kalimatnya sudah baik. Dalam berita ini terfokus pada penyesalan PSSI yang tidak bisa menahan kepergian Ratu Tisha dan Rencana PSSI untuk mencari penggantinya.

Retoris: Pemberitaan ini menambahkan foto jajaran PSSI pada periode saat ini, selebihnya dari kata maupun idiom tidak ada.

4. Judul: Resmi Mundur, Ini Pencapaian Ratu Tisha Selama Jadi Sekjen PSSI

Tanggal: 13 April 2020

Sintaksis: Judul dan Lead berita terhubung dengan baik dengan memberitakan mundurnya Ratu Tisha. Kutipan yang digunakan disini lebih mengarah kepada pernyataan-pernyataan Ratu Tisha selama menjabat sebagai Sekjen PSSI. Hanya saja, yang dibahas di berita ini bukan hanya mengenai pencapaian, tapi juga dugaan-dugaan permasalahan yang diduga Ratu Tisha turut terlibat, yang dimana dalam penutupnya Ratu Tisha siap membantu menyelesaikan permasalahan di sepak bola nansional.

Skrip: Pada sisi ini, komponen-komponen terisi secara lengkap, dan pada sisi ini lebih menonjolkan komponen how yang menceritakan apa saja pencapaian Ratu Tisha selama menjabat sebagai Sekjen PSSI.

Tematik: Dari sisi tematik, paragraf, proporsi kalimat, hubungan antar kalimatnya sudah baik. Pada berita ini memfokuskan kepada pencapaian yang dicapai oleh Ratu Tisha selaku Sekjen PSSI.

Retoris: Dalam pemberitaan ini, penulis berita hanya menambahkan gambar yang menampilkan Ratu Tisha dan pemain sepakbola nasional yang meraih prestasi di AFF Awards 2019.

5. Judul: Suka Duka Ratu Tisha Selama di PSSI

Tanggal: 14 April 2020

Sintaksis: Judul dalam berita ini menggambarkan adanya situasi naik turun yang dihadapi oleh Ratu Tisha dalam menjabat sebagai Sekjen di PSSI. Selain pencapaian, beberapa cerita buruk mengenai Ratu Tisha juga diberitakan di berita ini. Namun, terlepas naik turun nya suasana dalam pemberitaan disini, pernyataan atau kutipan yang disampaikan hanyalah sedikit

Skrip: Pada sisi ini, berita ini lebih menekankan why yang menanyakan situasinya bisa naik turun dan how sebagai representasi dari apa yang sudah dilakukan Ratu Tisha di PSSI.

Tematik: Dari sisi tematik, paragraf, proporsi kalimat, hubungan antar kalimatnya sudah baik. Bagaimana penulis berita menggambarkan dahulu secara keseluruhan sisi baiknya, baru diberitakan ke sisi negatifnya. 
Retoris: Pemberitaan ini menambahkan foto Ratu Tisha Destria berfoto bersama dengan Duta Besar Vietnam di Indonesia, Pham Vinh Quang.

6. Judul: Peninggalan Ratu Tisha, Pengamat: Konyol Jika Sekjen PSSI Tidak Paham Bola

Tanggal: 15 April 2020

Sintaksis: Judul yang menyematkan pernyataan yang bermanuver tajam bisa mengundang pembaca untuk membaca secara lebih lengkap. Karena padahal isi berita yang dimaksud ialah proses PSSI dalam mencari pengganti Ratu Tisha sebagai Sekjen PSSI. Kutipan atau pernyataan yang disampaikan juga menyinggung proses tersebut.

Skrip: Dalam sisi ini, pemberitaan ini lebih menekankan ke arah what sebagai representasi apa yang menjadi peninggalan Ratu Tisha sebagai Sekjen PSSI dan how yang menjadi representasi tugas dan tanggung jawab Sekjen PSSI sesuai dengan statuta PSSI.

Tematik: Dari sisi tematik, paragraf, proporsi kalimat, hubungan antar kalimatnya sudah baik. Penulis berita menggambarkan dahulu apa yang menjadi peninggalan, lalu membahas mengenai tanggung jawab Sekjen, lalu diakhiri dengan pernyataan dari perwakilan PSSI mengenai proses pencarian Sekjen PSSI yang baru.

Retoris: Pemberitaan ini menambahkan foto jajaran PSSI pada periode saat ini, selain itu juga kata konyol dalam judul dan pernyataan di isi berita merepresentasikan reaksi yang terjadi jika Sekjen PSSI nantinya tidak sesuai dengan kualifikasi dan ekspektasi. Di samping itu juga, berita ini melampirkan isi statute PSSI mengenai tugas dan tanggung jawab Sekjen PSSI.

7. Judul: Mundur dari PSSI, Ratu Tisha Diminta Menjadi Manajer Sriwijaya FC Tanggal: 14 April 2020

Sintaksis: Berdasarkan pada judul dan lead pada berita tersebut menyampaikan keinginan Sriwijaya FC agar Ratu Tisha menjadi manajer di klub Sriwijaya FC. Yang menjadi faktor kontroversialnya ialah pada kutipan di dalam berita ini menyampaikan bahwa "Sebagai Akun Resmi Sriwijaya FC, kami memiliki kewajiban untuk menyampaikan informasi terbaru mengenai yang dilakukan oleh Manajemen dan Tim,". Padahal seharusnya sebagai selayaknya akun resmi klub, Sriwijaya FC cukup memberitakan sesuatu hal yang sudah resmi, bukan yang masih menjadi rumor.

Skrip: Pada aspek ini, berita sudah cukup lengkap menjelaskan $5 \mathrm{~W}+1 \mathrm{H}$, namun pada berita ini lebih menekankan pada aspek who yang membincangkan pergantian manager Sriwijaya FC.

Tematik: Dari sisi tematik, berita ini menggabungkan berita mengenai isu masuknya Ratu Tisha menjadi manajer Sriwijaya FC dengan salam perpisahan Ratu Tisha yang diunggah ke dalam media sosial Instagram. 
Retoris: Pada aspek ini, berita mengutip unggahan Instagram dari akun resmi Sriwijaya FC yang meminta Ratu Tisha untuk menjadi manager Sriwijaya FC.

8. Judul: Ratu Tisha: Hati Saya kalau Dibelah, Isinya Hanya Sepak Bola. Tanggal: 13 April 2020

Sintaksis: Pada judul dan lead di berita ini sebenarnya tidak nyambung, di judul mengungkapkan pernyataan kecintaan Ratu Tisha terhadap sepak bola, sementara di lead membahas mundurnya Ratu Tisha. Di sisi lain, pada isi berita dan kutipan yang diberitakan juga membahas mengenai mundurnya Ratu Tisha dan pencapaian yang didapatkan oleh Ratu Tisha semasa menjabat Sekjen PSSI.

Skrip: Pada berita ini lebih menekankan di komponen who yang menceritakan siapa Ratu Tisha dan how sebagai representasi bagaimana proses dan pencapaian Ratu Tisha dalam menjabat sebagai Sekjen PSSI

Tematik: Dari sisi tematik, judul dan isi rasanya tidak nyambung. Dikarenakan judulnya mendeskripsikan kecintaan Ratu Tisha kepada sepak bola, namun di sisi lain di beritanya berisikan pencapaian dan perjalanan hidup dari Ratu Tisha.

Retoris: Dalam berita ini menunjukkan kalimat kiasan yang digunakan oleh Ratu Tisha, yakni "Hati Saya kalau Dibelah, Isinya Hanya Sepak Bola." Ini lebih menggambarkan kecintaan Ratu Tisha terhadap sepak bola, meskipun ia sudah tak lagi menjabat sebagai Sekjen di PSSI

9. Judul: Perjalanan Ratu Tisha, dari Ikut Master FIFA hingga Jadi Wakil Presiden AFF

Tanggal: 13 April 2020

Sintaksis: Berdasarkan judul dan lead, pemberitaan ini mengawalinya dengan kabar mundurnya Ratu Tisha sebagai Sekjen PSSI. Dari kutipan atau pernyataan yang disampaikan oleh Ratu Tisha mencerminkan ungkapan terima kasih dan ungkapan motivasi kepada sesama insan sepakbola nasional.

Skrip: Pada aspek ini secara 5W1H sudah lengkap, pada berita ini lebih menekankan kepada aspek who yang menggambarkan siapa Ratu Tisha dan How yang menggambarkan cerita Ratu Tisha selama menjadi Sekjen di PSSI.

Tematik: Dari sisi tematik, paragraf, proporsi kalimat, hubungan antar kalimatnya sudah baik dengan merunutkan kronologi perjalanan hidup dari Ratu Tisha

Retoris: Pemberitaan ini menambahkan foto Ratu Tisha dalam mengikuti wawancara.

10. Judul: Ini Syarat Menjadi Sekjen PSSI Pengganti Ratu Tisha

Tanggal: 14 April 2020

Sintaksis: Berdasarkan judul dan lead berita tersambung dan terfokus dengan baik. Kutipan yang disertakan dalam berita ini bersumber dari Statuta PSSI. 
Skrip: Pada sisi ini lebih menekankan ke komponen how sebagai reprsentasi bagaimana persyaratan untuk menjadi Sekjen PSSI.

Tematik: Dari sisi tematik, Berita ini memfokuskan ke arah kriteria dari Sekjen PSSI yang akan menggantikan Ratu Tisha.

Retoris: Dalam sisi ini, penulis berita hanya menambahkan foto Ratu Tisha.

b. Penemuan dan Pembahasan Berita dari Detik.com

1. Judul: Ratu Tisha Mundur dari Sekjen PSSI, Ada Apa?

Tanggal: 14 April 2020

Sintaksis: Berdasarkan judul dan lead berita yang disampaikan pada berita tersebut mendeskripsikan kebingungan mengapa hal tersebut terjadi atau apa yang membuat Ratu Tisha mengundurkan diri dari PSSI. Kutipan serta sumber pernyataan di berita ini yang juga menjadi penutup ialah dari Cucu Soemantri yang menjelaskan alasan berdasarkan pendapat pribadinya.

Skrip: Dalam berita ini aspek yang dikedepankan ialah komponen why sebagai representasi alasan mengapa Ratu Tisha mundur dari PSSI, dalam berita ini alasan tersebut dispekulasikan lewat kejadian beberapa saat sebelum mundurnya Ratu Tisha dan pendapat dari pihak PSSI. Dalam berita ini aspek 5W1H cukup terpenuhi.

Tematik: Dari sisi tematik, paragraf, proporsi kalimat, hubungan antar kalimatnya memfokuskan kepada alasan dari mundurnya Ratu Tisha, walaupun beberapa alasan yang disampaikan masih berbentuk spekulasi.

Retoris: Dalam aspek ini, Kalimat "Adapun wakil ketum Cucu Somantri sempat mengatakan Tisha ingin berbakti di tempat lain. Tersirat bahwa keputusan Tisha mundur diambil atas inisiatifnya." Ini mengundang banyak pertanyaan dan spekulasi dimana Pelabuhan Ratu Tisha setelah menjabat menjadi sekjen di PSSI. Di samping itu hingga penelitian ini ditulis, Ratu Tisha belum juga ditemukan dimana ia bekerja setelah dari PSSI.

2. Judul: Mundur dari Sekjen PSSI, Ratu Tisha Digantikan Adik Ipar Sang Ketum? Tanggal: 14 April 2020

Sintaksis : Berdasarkan judul dan lead berita yang disampaikan pada berita ini seperti mendeskripsikan pertanyaan dan jawaban, yang dimana judul sebagai pertanyaan dan lead berita sebagai jawaban yang mendeskripsikan siapa yang akan menggantikannya. Namun, kutipan dan sumber pernyataan disini yang berasal dari beberapa pengurus PSSI menyimpulkan sebuah penolakan atas judul tersebut. Sehingga berita ini hanya sebuah rumor belaka.

Skrip: Pada aspek ini mengedepankan komponen who sebagai representasi pertanyaan siapa yang akan menjadi sekjen selanjutnya, serta merepresentasikan unsur why, dikarenakan dalam berita ini juga menanyakan apa yang menjadi alasan jika Sekjen mengundurkan diri harus diganti dengan Wakil sekjennya.

Tematik: Dari sisi tematik, paragraf, proporsi kalimat, hubungan antar kalimatnya sudah baik. Bagaimana kalimat tanya sebagai judul ditimpali jawaban 
pada bagian lead. Pada bagian isi diisi beberapa kutipan sebagai respons dari pertanyaan yang berperan sebagai judul.

Retoris: Pada aspek ini, pernyataan dari Haruna Soemitro yang mengatakan "Tolong kasih tahu saya yang berasal dari desa ini, kalau Sekjen mundur apakah penggantinya harus Wakil Sekjen?" ini menjadi spekulasi dalam berita ini, karena apa yang sebenarnya dimaksud dengan desa? Apakah ini perumpamaan atau typo. Pernyataan ini juga mengandung tanya kembali yang akhirnya belum terjawab pada berita ini.

3. Judul: Ratu Tisha Mundur dari Kursi Sekjen PSSI

Tanggal: 13 April 2020

Sintaksis: Berdasarkan judul dan lead berita yang disampaikan tersambung dengan baik dengan melampirkan ungkapan perpisahan Ratu Tisha yang ia sampaikan di Instagram. Terlepas dari itu, kutipan dan sumber pernyataan yang disampaikan pada berita ini lebih menonjolkan alasan yang menjadi spekulasi, bahkan cenderung melakukan cocokologi terhadap situasi yang terjadi sebelum mundurnya Ratu Tisha.

Skrip: Pada aspek dalam pemberitaan ini secara aspek 5W1H sudah cukup terpenuhi, hanya saja pada sisi ini lebih mengedepankan what sebagai representasi apa yang menjadi inti beritanya dan why sebagai representasi spekulasi alasan yang dicantumkan pada berita ini.

Tematik: Dari sisi tematik, paragraf, proporsi kalimat, hubungan antar kalimatnya sudah baik

Retoris: Pada aspek ini, pada kalimat "Djohar menyebut Tisha kerap kebablasan dalam tugasnya." Menjadi spekulasi dalam berita ini, apa yang dimaksud dengan "kebablasan" yang disampaikan pada berita ini. Itu tidak disampaikan dalam berita.

4. Judul: Ratu Tisha Mundur dari PSSI karena Kritik Djohar atau Hal Lain? Tanggal: 15 November 2020

Sintaksis: Berdasarkan pada berita yang disampaikan, judul yang mengajukan pertanyaan belum bisa terjawab di lead beritanya. Sementara kutipankutipan dari beberapa sumber pernyataan seperti bermain aman dan cenderung berspekulasi dengan kemungkinan yang ada. Sementara itu, terdapat kutipan dari Pasal 40 Statuta PSSI yang menyatakan "Mengangkat atau memberhentikan Sekretaris Jenderal atas usulan Ketua Umum. Sekretaris Jenderal harus memenuhi persyaratan sebagaimana diatur dalam Statuta PSSI."Namun di berita ini tidak dijelaskan persyaratan apa yang dipenuhi oleh Ratu Tisha sehingga ia bisa mengundurkan diri, terlepas memang dalam pasal tersebut tertulis diberhentikan, bukan saat mengundurkan diri."

Skrip: Pada aspek ini, aspek 5W1H cukup terpenuhi, selain itu komponen why menjadi komponen yang ditonjolkan sebagai representasi alasan Ratu Tisha mundur. Meskipun dari isi berita tidak menunjukkan kebenaran alasan yang ditanyakan pada judul. 
Tematik: Dari sisi tematik, berita ini lebih memfokuskan kepada alasan mundurnya Ratu Tisha, walaupun tidak ada satupun pernyataan di berita tersebut yang mampu menjadi alasan resmi dari kejadian tersebut.

Retoris: Dalam aspek ini, penulis berita hanya menambahkan foto sebagai pelengkap dari isi berita.

5. Judul: Mundur Jadi Sekjen PSSI, Ratu Tisha Kok Masih Puasa Bicara?

Tanggal: 15 April 2020

Sintaksis: Berdasarkan pada judul dan lead berita yang disampaikan, judul yang mengambil peran sebagai pertanyaan, dijawab oleh lead berita yang menyimpulkan dari beberapa Tindakan kecil Ratu Tisha saat mengundurkan diri dari PSSI. Sementara kutipan dan sumber pernyataan yang disampaikan di berita lebih mengarah kepada beberapa kejadian yang dilakukan oleh Ratu Tisha sebelum dia mundur dari PSSI. Hal ini cenderung mencocokkan situasi terhadap keputusannya, tanpa mendapatkan alasan yang sebenarnya terjadi.

Skrip: Pada aspek ini, aspek 5W1H cukup terpenuhi, di sisi lain aspek ini juga lebih mengedepankan ke aspek why sebagai representasi alasan yang ditanyakan pada judul, meskipun sempat terjawab mengapa Ratu Tisha puasa bicara. Lalu komponen how ditonjolkan disini sebagai cerita dari kejadian yang terjadi serta bagaimana proses kebijakan dan tanggung jawab seorang Sekjen PSSI.

Tematik: Dari sisi tematik, pemberitaan ini lebih memfokuskan kepada sikap Tisha setelah ia menyatakan mundur dari jabatannya sebagai Sekjen PSSI. Dalam pemberitaan ini juga menjelaskan bagaimana peran yang dijalankan oleh seorang Sekjen PSSI.

Retoris: Dari aspek ini, sebenarnya ada beberapa pernyataan yang mengundang spekulasi, hanya saja yang paling mengundang tebak-tebakan ialah pernyataan "Ada selentingan hubungan yang sudah tak harmonis antara Tisha dengan sosok internal PSSI.”. Menjadi sebuah pertanyaan besar siapa sosok internal yang kesannya memiliki masalah dengan Ratu Tisha.

6. Judul: Ratu Tisha Mundur dari PSSI, Umuh: Mungkin Nyaman Tak Jadi Sekjen Lagi

Tanggal: 14 April 2020

Sintaksis: Judul dan lead berita tersambung dengan baik. Di samping itu kutipan dan sumber pernyataan yang disampaikan sebenarnya cenderung menebak-nebak sehingga seperti berita lainnya tidak menemukan alasan yang pasti mengapa Ratu Tisha mengundurkan diri dari PSSI.

Skrip: Pada aspek ini lebih menonjolkan komponen why sebagai representasi alasan-alasan yang diprediksi oleh Umuh Muchtar.

Tematik: Dari sisi tematik, berita ini memfokuskan kepada subjektifitas Umuh Muchtar dalam memprediksi alasan yang menjadi penyebab mundurnya Ratu Tisha.

Retoris: Dalam aspek ini penulis berita hanya menambahkan foto Ratu Tisha. 
7. Judul: Kiprah Ratu Tisha Selama Menjabat sebagai Sekjen PSSI

Tanggal: 13 April 2020

Sintaksis: Judul dan lead berita yang disampaikan tersambung secara baik dengan menyebutkan rencana yang menjadi prioritas Ratu Tisha saat menjadi Sekjen PSSI, yakni pengembangan sumber daya manusia. Kutipan yang disampaikan pada berita ini ialah kutipan kalimat yang menunjukkan kecintaan Ratu Tisha terhadap sepak bola, yang digunakan sebagai penutup dalam berita.

Skrip: Pada aspek ini, aspek 5W1H cukup terpenuhi, selain itu komponen how lebih ditonjolkan sebagai representasi perjalanan Ratu Tisha selama menjabat sebagai Sekjen PSSI.

Tematik: Dari sisi tematik, berita ini memfokuskan kepada perjalanan karier Ratu Tisha sebagai Sekjen PSSI.

Retoris: Dalam aspek ini penulis berita menambahkan foto Ratu Tisha dan terdapat satu kalimat kiasan yang menunjukkan kecintaan Ratu Tisha terhadap sepak bola dengan berkata " Hati saya, kalau dibelah, isinya hanya sepakbola. I have loved you for a thousand years, and I will love you for a thousand more. Because we love football," (Robbani 2020).

8. Judul: Exco PSSI: Sekjen Baru PSSI Jangan Seperti Ratu Tisha Tanggal: 18 April 2020

Sintaksis: Judul dan lead berita tersambung secara baik, hal ini juga didukung oleh informasi, kutipan, dan sumber pernyataan yang mendukung, yakni alasan mengapa judul tersebut dinyatakan, yakni pengurus PSSI itu ingin Sekjen selanjutnya hanya focus mengerjakan tugas yang ada di Internal organisasi.

Skrip: Unsur 5W1H dalam berita ini cukup terpenuhi, dalam berita ini juga komponen why menjadi aspek yang ditonjolkan karena beberapa alasan diungkapkan di dalam berita.

Tematik: Dari sisi tematik, berita ini memfokuskan kepada kainginan Pengurus PSSI agar Ratu Tisha tidak melanglang buana kesana kemari melakukan pendekatan dengan pihak lain, cukup fokus melakukan pekerjaan yang ada di PSSI saja.

Retoris: Dari aspek ini, sebenarnya penggunaan kalimat "Jangan Seperti Ratu Tisha" mengundang banyak spekulasi dan pertanyaan serta menimbulkan multitafsir di kalangan pembaca, serta mengundang kesan negatif.

9. Judul: Perpisahan Ratu Tisha: Isi Hati Saya Cuma Ada Sepakbola Tanggal: 13 April 2020

Sintaksis: Judul dan lead berita, informasi, kutipan, dan sumber pernyataan tersambung secara baik. Berita ini memfokuskan diawali dengan bagaimana perasaan Ratu Tisha saat ia harus mengundurkan diri dari PSSI, selain itu pada berita ini juga disampaikan bagaimana pencapaian Ratu Tisha sebagai Sekjen PSSI sebagai lambang kecintaannya pada sepakbola. 
Skrip: Berita ini lebih mengedepankan komponen what sebagai representasi dari apa yang ingin disampaikan oleh Ratu Tisha setelah menyatakan mengundurkan diri dari PSSI.

Tematik: Dari sisi tematik, berita ini memfokuskan kepada kecintaan Ratu Tisha terhadap sepak bola, Meskipun isi beritanya hanyalah repetisi dari beritaberita yang lain serta unggahan Instagram Ratu Tisha.

Retoris: Dalam kalimat yang digunakan oleh Ratu Tisha, yakni "Hati Saya kalau Dibelah, Isinya Hanya Sepak Bola.” Ini lebih menggambarkan kecintaan Ratu Tisha terhadap sepak bola, meskipun ia sudah tak lagi menjabat sebagai Sekjen di PSSI.

10. Judul : Ratu Tisha Mundur Jadi Sekjen, Ini Respons Ketum PSSI

Tanggal : 13 April 2020

Sintaksis : Judul dan lead berita, informasi, kutipan, dan sumber pernyataan tersambung secara baik bagaimana Ketua Umum PSSI menghargai keinginan Ratu Tisha untuk mengundurkan diri serta mengucapkan terima kasih atas pengabdian yang dilakukan oleh Ratu Tisha.

Skrip: Berita ini lebih mengedepankan komponen what sebagai representasi dari apa yang ingin disampaikan oleh Ketua umum PSSI sebagai respons setelah Ratu Tisha menyatakan mengundurkan diri dari PSSI.

Tematik: Dari sisi tematik, berita ini hanya menyampaikan apa yang menjadi respons dari Ketua Umum PSSI.

Retoris: Pemberitaan ini menambahkan foto Ratu Tisha bersama Ketua Umum (Ketum) PSSI Mochamad Iriawan

\section{Kesimpulan}

Dari analisis framing pada media online Detik.com dan Kompas.com mengenai pemberitaan tentang mundurnya Ratu Tisha dari Jabatan Sekretaris Jenderal PSSI edisi 13 - 18 April 2020, dapat dibagi menjadi beberapa kesimpulan, yaitu: (1.) Kompas.com dalam memberikan headline cenderung menyampaikan secara biasa sesuai dengan isi dari beritanya, sementara Detik.com memberikan headline dominannya dengan menyampaikan pertanyaan untuk menarik atensi dari pembaca. (2.) Dalam menyampaikan pemberitaan yang mengedepankan unsur why (mengapa), Detik.com cenderung memberikan pernyataan yang abu-abu dan tidak pasti, sehingga meskipun headline yang sudah disampaikan sudah menarik perhatian, namun isi beritanya terkadang tidak memberikan jawaban apapun dari judul atau pertanyaan tersebut. (3.) Kompas.com dalam menyampaikan beritanya cenderung deskriptif dan bermain di jalur yang aman, sementara Detik.com terkadang membuat pernyataan dan headline yang tendensius. 


\section{BIBLIOGRAFI}

Agustiyani, Dian. (2016). Keefektifan Pembelajaran Menulis Teks Berita Menggunakan Model Peta Konsep Dan Model Investigasi Kelompok Pada Siswa Kelas VIII. Universitas Negeri Semarang.Google Scholar

Andarista, Neyna Vandarani. (2017). Analisis Framing Pemberitaan Chatting Seks Habib Rizieq di Media Liputan6. com. Jurnal Spektrum Komunikasi, 5(1). Google Scholar

Ardy, Vera Widiaswari. (2011). Konstruksi Pemberitaan Mundurnya Sri Mulyani Sebagai Menkeu Oleh Surat Kabar Analisis Framing Pada Harian Kompas Dan Media Indonesia. University of Muhammadiyah Malang. Google Scholar

Binti, Miftahul. (2018). Sandiaga Uno Dalam Bingkai Berita (Analisis Framing Kemacetan Tanah Abang pada Media Online CNNIndonesia. com dan Kompas. com edisi 06 dan 07 November 2017). Universitas Muhammadiyah Ponorogo. Google Scholar

Chandra, Devi. (2018). Analisis Berita Kriminal Pada Surat Kabar Harian Seru Jambi (Studi Kasus Berita Penyalahgunaan Narkoba). Uin Sulthan Thaha Saifuddin Jambi. Google Scholar

CNN Indonesia. (2021). Helmy Yahya: Hak Siar Liga 1 Lebih Mahal dari Liga Inggris. January 28, 2020. Retrieved from https://www.cnnindonesia.com/olahraga/202001 28183615-142-469545/helmy-yahya-hak-siar-liga-1-lebih-mahal-dari-liga-inggris.

Handoko, Nasario Wahyu, Emeraldien, Fikry Zahria, \& Purnomo, Aldi. (2020). Analisis Framing Terhadap Pemberitaan Klub Sepak Bola Persebaya. Jurnal Penjakora, 6(2), 82-91. Google Scholar

Harahap, Raufuddin. (2019). Opini Masyarakat Dalam Meningkatkan Kewaspadaan Terkait Berita Kriminal Di Medanheadlines. Com.Google Scholar

Hodijah, Nur Siti. (2015). Faktor-Faktor Pendorong Yang Mempengaruhi Suporter Lanus Mendukung Pscs Cilacap Tahun 2015. Universitas Negeri Semarang. Google Scholar

Maulana, Yudhi. (2020). Mundur dari Sekjen PSSI, Ini 5 Pencapaian Gemilang Ratu Tisha. Retrieved from https://www.viva.co.id/bola/liga-indonesia/1210566mundur-dari-sekjen-pssi-ini-5-pencapaian-gemilang-ratu-

tisha?page=all\&utm_medium=all-page $($ accessed March 14, 2021).

Mustika, Rieka. (2018). Etika Berkomunikasi Di Media Online Dalam Menangkal Hoax. Diakom: Jurnal Media Dan Komunikasi, 1(2), 43-50. Google Scholar

Novianti, Evi. (2019). Pemaknaan Nyadaran Sebagai Pelestarian Budaya Pada Etnik Jawa. Dan Dokumentasi Kontemporer. Google Scholar 
Pratiwi, Siti. (2018). Konstruksi Pemberitaan Gerakan\# 2019GantiPresiden (Analisis Framing Robert $N$ Entman pada Kompas. com dan Detik. com). Universitas Islam Negeri Alauddin Makassar. Google Scholar

Putra, Abraham, \& Larasati, Retno Wahyu. (2021). Analisis Framing Pemberitaan Media Online Tribunjogja. com dan Detik. com (Kasus Suap Taufik Hidayat dan Eks Menpora). Jurnal Audience: Jurnal Ilmu Komunikasi, 4(01), 128-140. Google Scholar

Rahmawati, Shintya. (2021). Bahasa jurnalistik dalam berita pendidikan harian Pikiran Rakyat edisi Juli 2021: Studi deskriptif kualitatif penggunaan bahasa jurnalistik sesuai konsep Yus Badudu. UIN Sunan Gunung Djati Bandung. Google Scholar

Restendy, Mochammad Sinung. (2017). Daya Tarik Jurnalistik, Pers, Berita Dan Perbedaan Peran Dalam News Casting. Al-Hikmah: Jurnal Kependidikan Dan Syariah, 4(2), 1-12. Google Scholar

\section{Copyright holder:}

Fadli Muhammad Athalarik, Fina Zahra (2021)

\section{First publication right:}

Syntax Idea

This article is licensed under:

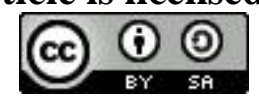

